\title{
Implementasi Good Governance Pada Organisasi Mahasiswa
}

\author{
Sulastri ${ }^{\mathrm{a}, 1 *}$, Ichwani Siti Utami ${ }^{\mathrm{b}, 2}$ \\ a,b Prodi Pendidikan Pancasila dan Kewarganegaraan, Fakultas Keguruan dan Ilmu Pendidikan, Universitas \\ Pamulang \\ ${ }^{1}$ dosen02081@unpam.ac.id; ${ }^{2}$ dosen00699@unpam.ac.id \\ *korespondensi penulis
}

Naskah diterima: 23 Agustus 2020, direvisi: 1 September 2020, disetujui: 15 September 2020

\begin{abstract}
Abstrak
Organisasi mahasiswa di seluruh Fakultas Universitas Pamulang khususnya bidang eksekutif yang dijalankan oleh mahasiswa telah berkembang pesat dalam segi kuantitas. Akan tetapi, dalam menjalankan tata kelola organisasinya masih belum optimal. Sering terjadi ketidakjelasan dan kebingungan dalam mengatur dan mengelola organisasi mahasiswanya secara baik dan benar.Terlihat masih minimnya peran aktif mahasiswa di seluruh Fakultas Universitas Pamulang untuk ikut berpartisipasi demi mewujudkan tata kelola organisasi mahasiswa. Partisipasi, akuntabilitas dan transparansi tersebut merupakan bagian dari prinsip good governance yang harus dijalankan dengan baik dalam sebuah organisasi. Oleh karena itu tujuan penelitian ini dilakukan untuk mengetahui bagaimana implementasi ketiga prinsip good governance tersebut pada organisasi mahasiswa di Universitas Pamulang. Metode dalam penelitian ini yakni kualitatif dengan jenis pendekatan normatif-empiris. Hasil penelitian ini menunjukan masih minimnya partisipasi keaktifan pengurus organisasi mahasiswa dari beberapa program studi, transparansi dokumen dan kebijakan lainnya hanya bisa dikonsumsi atau diketahui oleh pengurus mahasiswa dan tidak dipublikasikan untuk umum karena hanya beberapa prodi yang mempublikasikan, sedangkan akuntabilitas dokumen sudah dilaksanakan dengan baik. Dari hal tersebut maka implementasi good governance pada prinsip partisipasi, transparansi dan akuntabilitas pada organisasi mahasiswa di Universitas Pamulang belum sepenuhnya berjalan baik. Oleh karena itu perlu adanya sebuah kebijakan dari yang menaungi organisasi tersebut agar dapat menjalankan ketiga prinsip good governance dengan baik.
\end{abstract}

Kata-kata kunci: Implementasi; good governance; organisasi mahasiswa

\footnotetext{
Abstract

Student organizations throughout the Faculty of Pamulang University, especially the executive sector, which are run by students, have developed rapidly in terms of quantity. However, in carrying out the organizational governance is still not optimal. There is often uncertainty and confusion in regulating and managing student organizations properly and correctly. There is still a lack of active role of students in all faculties of Pamulang University to participate in realizing student organizational governance. Participation, accountability and transparency are part of the principles of good governance that must be carried out well in an organization. Therefore, the purpose of this study was to determine how the implementation of the three principles of good governance in student organizations at Pamulang University. The method in this research is qualitative with a normative-empirical approach. The results of this study indicate the lack of active participation of the management of student organizations from each study program, transparency of documents and other policies can only be consumed or known by student administrators and not published to the public, accountability is still not optimal. From this, the implementation of good governance on the principles of participation, transparency and accountability in student organizations at Pamulang University has not been fully implemented. Therefore, it is necessary to have a policy that covers the organization so that it can carry out the three principles of good governance properly.
}

Key words: Implementation; good governance; student organizations 


\section{Pendahuluan}

Mahasiswa merupakan insan intelektual yang akan menjadi generasi penerus bangsa di masa depan. Dalam mengembangkan dirinya, mahasiswa tidak hanya bisa memanfaatkan ruang kuliah sebagai tempat belajar, berhimpun dalam organisasi kemahasiswaan juga merupakan sarana belajar bagi setiap mahasiswa untuk bisa mengembangkan kemampuan intelektual, kemampuan sosial dan kemampuan religiusnya.

Organisasi kemahasiswaan yang dibentuk oleh mahasiswa merupakan miniature state atau student goverment yang melaksanakan tugas dan fungsi seperti sebuah negara. Konsekuensi dari organisasi kemahasiswaan sebagai student government adalah segala aktivitasnya merupakan aktivitas politik. Politik adalah segala hal yang terkait dengan penyelenggaraan negara dan pemerintahan. Jadi bisa dikatakan bahwa dengan mengikuti organisasi kemahasiswaan maka seorang mahasiswa sedang belajar berpolitik. Akan tetapi ranah politiknya dalam ruang lingkup kecil yakni di lingkungan kampus.

Sebagaimana diketahui, Universitas Pamulang di dalam sejarah kemahasiswaannya merupakan salah satu motor pergerakan mahasiswa Indonesia dalam mewujudkan pemerintahan yang demokratis. Hal tersebut tidak terlepas dari peran aktif mahasiswa dan organisasi mahasiswa di Universitas Pamulang yang berpikiran kritis dan idealis yang berkeinginan untuk menciptakan suatu negara yang adil dan makmur.

Dalam perkembangan sekarang ini, organisasi mahasiswa di seluruh Fakultas Universitas Pamulang khususnya bidang eksekutif yang dijalankan oleh mahasiswa telah bekembang pesat dalam segi kuantitas. Akan tetapi, para organisasi mahasiswa tersebut dalam menjalankan tata kelola organisasinya terkadang masih tidak optimal. Sering terjadi ketidakjelasan dan kebingungan dalam mengatur dan mengelola organisasi mahasiswanya secara baik dan benar serta peran aktif mahasiswanya pun belum optimal.

Terlihat masih minimnya peran aktif mahasiswa di seluruh Fakultas Universitas Pamulang untuk ikut berpartisipasi demi mewujudkan tata kelola organisasi mahasiswa di kampusnya agar lebih baik. Hal inilah yang memperlihatkan banyak mahasiswa yang apatis terhadap aktivitas politik.

Selain itu, masih adanya usaha untuk membangun monoloyalitas secara sistematis yang mengakibatkan tidak terciptanya kondisi saling mengawasi (checks and balances sistem) antar organisasi kemahasiswaan, sehingga tidak akuntabel. Transparansi, partisipasi dan akuntabilitas seharusnya merupakan tugas dasar sebuah organisasi mahasiswa. Ketiga hal itu pula adalah beberapa prinsip yang ada di dalam good governance. Perlunya menerapkan prinsip-prinsip tersebut kedalam sebuah organisasi itu karena dengan diterapkannya good governance di tata kelola organisasi mahasiswa, maka terwujudlah good student governance.

Dalam konteks pemerintahan yang baik, salah satu kunci sukses terpenting dari adanya perubahan dalam proses governance terletak pada individu-individu yang ada di dalam proses governance itu sendiri. Terdapat 4 alasan resistensi individu terhadap perubahan yaitu: kepentingan pribadi, rendahnya tingkat kepercayaan, perbedaan pandangan/penilaian, rendahnya toleransi terhadap perubahan.

Apabila beberapa prinsip di atas selama ini tidak diimplementasikan, maka harus dicari faktor penyebabnya agar kedepan dapat menerapkan good student governance. Untuk itu perlulah dibuat atau dipertegas penerapan good governance di organisasi mahasiswa di Universitas Pamulang. Dengan demikian, mahasiswa dapat belajar bagaimana 
menjalankan sebuah tatanan pemerintahan yang baik dalam sebuah organisasi yang di kemudian hari bisa diaplikasikan ketika masuk ke dalam pemerintahan.

\section{Metode}

Tempat penelitian ini dilaksanakan di Universitas Pamulang dengan jangka waktu selama 6 bulan. Penelitian ini adalah penelitian hukum. Metode yang digunakan yakni kualitatif dengan jenis penelitian normatif-empiris. Kemudian data yang digunakan yakni data sekunder dan data primer. Untuk data sekunder mengacu kepada perundang-undangan atau kebijakan yang berlaku yang terkait dengan masalah penelitian, kemudian data primer didapatkan dari wawancara kepada subjek penelitian. Subjek penelitian dibagi dua macam yaitu responden dan narasumber. Responden di dalam penelitian ini adalah mahasiswa dan narasumber pimpinan beserta pengurus organisasi mahasiswa di semua Fakultas Universitas Pamulang.

Tahapan Penelitian mengacu pada model penelitian yang sudah ditentukan, maka penelitian ini memiliki beberapa tahapan yang dimulai dari; 1) penelitian pendahuluan; 2) penyusunan rencana penelitian; 3) inventarisir data-data penelitian; dan 4) analisis dan kesimpulan.

\section{Hasil dan Pembahasan}

Terhimpun dalam organisasi kemahasiswaan merupakan hak bagi setiap mahasiswa. Seperti diatur di dalam Undangundang Nomor 12 Tahun 2012 tentang Pendidikan Tinggi pasal 77 ayat 1 sampai 3 yang menyatakan bahwa : 1) Mahasiswa dapat membentuk organisasi kemahasiswaan. 2) Organisasi kemahasiswaan paling sedikit memiliki fungsi untuk: a. mewadahi kegiatan Mahasiswa dalam mengembangkan bakat, minat, dan potensi Mahasiswa; b. mengembangkan kreativitas, kepekaan, daya kritis, keberanian, dan kepemimpinan, serta rasa kebangsaan; c. memenuhi kepentingan dan kesejahteraan Mahasiswa; dan d. mengembangkan tanggung jawab sosial melalui kegiatan Pengabdian kepada Masyarakat. 3) Organisasi kemahasiswaan sebagaimana dimaksud pada ayat (1) merupakan organisasi intra Perguruan Tinggi.

Lembaga mahasiswa adalah sebuah wadah pembelajaran mahasiswa untuk mengembangkan diri dalam berorganisasi, kepemimpinan, dan belajar menjalankan kegiatan, dari mulai yang bersifat akademik maupun non-akademik. Tujuan dari lembaga mahasiswa didirikan yakni untuk membuat suatu lembaga pemerintahan internal kampus dengan tujuan membantu pencapaian visi suatu universitas. Tidak hanya itu, lembaga mahasiswa juga bertujuan untuk menanamkan budaya kritis dan kepekaan sosial kepada setiap mahasiswa terhadap internal universitas dalam hal mengkritisi setiap kebijakan rektor beserta jajarannya maupun persoalan terhadap pemerintahan negara.

Organisasi mahasiswa atau biasa juga dikenal sebagai organisasi kemahasiswaan merupakan bentuk kegiatan di perguruan tinggi yang diselenggarakan dengan prinsip dari, oleh dan untuk mahasiswa. Kemudian menurut Keputusan Menteri Pendidikan dan Kebudayaan RI Nomor 155/U/1998 Tentang Pedoman Umum Organisasi Kemahasiswaan di Perguruan Tinggi, menyebutkan bahwa "Organisasi kemahasiswaan intra-perguruan tinggi adalah wahana dan sarana pengembangan diri mahasiswa ke arah perluasan wawasan dan peningkatan kecendikiaan serta integritas kepribadian untuk mencapai tujuan pendidikan tinggi”.

Demi menjadikannya sebagai wahana dan sarana pengembangan diri mahasiswa, tentunya dibutuhkan peran aktif berupa partisipasi dari mahasiswa dalam menjalankan 
organisasi mahasiswa itu sendiri. Keterlibatan aktif dalam berpartisipasi, bukan hanya keterlibatan jasmaniah semata. Partisipasi dapat diartikan sebagai keterlibatan mental, pikiran, dan emosi atau perasaan seseorang dalam situasi kelompok yang mendorongnya untuk memberikan sumbangan kepada kelompok dalam usaha mencapai tujuan serta turut bertanggung jawab terhadap usaha yang bersangkutan (Siregar, 2016:58).

Oleh karena itu dalam melaksanakan kegiatan organisasi mahasiswa perlu partisipasi yang tinggi dari para mahasiswa. Mahasiswa yang aktif mengikuti organisasi kemahasiswaan mempunyai kesempatan yang lebih besar untuk berinteraksi dengan individuindividu lain dibandingkan dengan mahasiswa yang tidak aktif dalam organisasi kemahasiswaan. Hal ini tentunya semakin memperkaya pengalaman mereka yang terlibat aktif dalam organisasi kemahasiswaan dalam menghadapi individu-individu dengan berbagai karakter kepribadian. Dengan perkataan lain, mahasiswa yang aktif mengikuti organisasi kemahasiswaan lebih terlatih secara sosial dan lebih kompeten dalam menghadapi berbagai situasi interpersonal dibandingkan dengan mahasiswa yang jarang atau bahkan tidak pernah aktif dalam organisasi kemahasiswaan.

Partisipasi yang dilakukan bisa dengan cara langsung maupun tidak langsung. Untuk mengoptimalkan kegiatan sebuah organisasi maka kedua hal partisipasi tersebut harus dijalankan dengan baik. Seperti halnya dalam organisasi mahasiswa di universitas pamulang dilakukan secara langsung dan tidak langsung.

Hal tersebut sesuai dengan apa yang disampaikan oleh salah satu pembina himpunan mahasiswa pada program studi pendidikan dan kewarganegaraan universitas pamulang yakni bapak Herdi wisman Jaya., S.Pd., MH menyatakan bahwa suatu organisasi akan berjalan dengan baik jika partisipasi dari mahasiswa dilaksanakan secara langsung maupun tidak langsung. Idealnya partisipasi secara langsung dilaksanakan oleh pengurus himpunan mahasiswa dari setiap program studi, kemudian partisipasi secara tidak langsung dilaksanakan oleh mahasiswa diluar dari pengurus himpunan mahasiswa. Karena partisipasi tersebut merupakan salah satu prinsip good governance yang harus dilaksanakan dalam sebuah organisasi.

Partisipasi dibagi menjadi 2 (dua) berdasarkan cara keterlibatannya, yaitu : partisipasi langsung dan tidak langsung. Partisipasi secara langsung yang dilaksanakan oleh pengurus himpunan mahasiswa pada universitas Pamulang masih minim. Hal itu terlihat dari data yang didapatkan dari 15 program studi di Universitas Pamulang. Lebih jelasnya disajikan pada tabel dibawah ini:

Tabel 1. Nama tabel

\begin{tabular}{lcc}
\hline \multirow{2}{*}{ Program Studi } & \multicolumn{2}{c}{ Partisipasi } \\
\cline { 2 - 3 } & $\begin{array}{c}\text { Jumlah } \\
\text { Pengurus }\end{array}$ & $\begin{array}{c}\text { Yang } \\
\text { aktif }\end{array}$ \\
\hline S1 Manajemen & 165 & 50 \\
\hline S1 Akuntansi & 140 & 45 \\
\hline D3 Akuntansi & 24 & 24 \\
\hline D3 Sekretaris & 25 & 25 \\
\hline S1 Teknik Mesin & 30 & 30 \\
\hline S1 Teknik Industri & 26 & 26 \\
\hline S1 Teknik Kimia & 21 & 13 \\
\hline S1 Teknik & 28 & 28 \\
Informatika & & \\
\hline S1 Teknik Elektro & 25 & 25 \\
\hline S1 Matematika & 23 & 22 \\
\hline S1 Sastra Inggris & 27 & 27 \\
\hline S1 Sastra & 30 & 10 \\
Indonesia & & \\
\hline S1 Hukum & 82 & 44 \\
\hline S1 PPKn & 37 & 37 \\
\hline S1 Pendidikan & 28 & 18 \\
Ekonomi & & \\
\hline \multicolumn{1}{c}{ Sum }
\end{tabular}

Sumber: data hasil observasi penulis, 2020 
Tabel 1 menunjukkan bahwa partisipasi secara langsung yang dilaksanakan oleh pengurus Himpunan Mahasiswa Universitas Pamulang masih belum sepenuhnya maksimal. Hal tersebut terjadi karena berbagai faktor. Seperti yang dijelaskan pada saat wawancara oleh salah satu ketua HIMA program studi pendidikan ekonomi yakni wahyu bahwa pertama keterbatasan waktu untuk terjun dalam kegiatan karena memiliki banyak kegiatan lainnya diluar perkuliahan, kemudian ditambah pada masa pandemi covid 19 ini bahwa keaktifan semakin berkurang karena dilaksanakan secara online. Selain itu keterbatasan ekonomi akibat pandemi, serta kurangnya komunikasi. Beberapa faktor diatas sangat mempengaruhi penurunan partisipasi dalam kegiatan Himpunan Mahasiswa.

Hal lain juga disampaikan oleh Ajeng sebagai ketua umum HIMA Program Studi sastra Indonesia bahwa partisipasi aktif kepengurusan HIMA belum sepenuhnya aktif karena dua bulan setelah pelantikan kepengurusan langsung adanya wabah covid 19 ini sehingga semua kegiatan tidak bisa berjalan atau tertunda sehingga partisipasi pengurus pun tidak maksimal.

Keaktifan pengurus organisasi mahasiswa merupakan indikator pertama dari implementasi prinsip good governance yakni partisipasi. Selain itu masih ada beberapa indikator di dalam prinsip partisipasi yakni keterlibatan pengurus dalam pengambilan keputusan atau kebijakan.

Dari hasil wawancara salah satu pengurus Himpunan mahasiswa program studi pendidikan kewarganegaraan bidang PMSK saudara KGS Rizky Ahmad mengatakan bahwa dalam setiap penentuan kebijakan terutama untuk kebijakan yang berhubungan dengan kegiatan maka seluruh pengurus Himpunan Mahasiswa ikut andil. Penentuan kebijakan dijalankan pada awal masa kerja atau periode yang dihadiri oleh seluruh pengurus dan pembina. Jadi semua memberikan partisipasi aktif dalam penentuan kebijakan.

Hal yang sama disampaikan oleh saudara Aprizal Mulya Pramana perwakilan pengurus Himpunan mahasiswa program studi Teknik Kimia bahwa keterlibatan dalam pengambilan kebijakan atau keputusan itu berdasarkan musyawarah pengurus dan tidak sepihak sehingga semua kebijakan dibuat dengan bersama dan dilaksanakan secara bersama pula. Indikator prinsip partisipasi yang ketiga yakni ketersediaan forum atau media bagi partisipasi mahasiswa. Dari hasil wawancara semua program studi menyatakan bahwa terdapat media atau forum bagi partisipasi mahasiswa bak itu untuk kepengurusan Himpunan mahasiswa maupun untuk mahasiswa diluar dari kepengurusan. Media yang digunakan yakni whatsapp grup, dan aplikasi lainnya seperti google meet dan zoom. Seperti yang disampaikan oleh ketua himpunan mahasiswa program studi D3 Akuntansi bahwa wadah atau media terutama whatsapp digunakan untuk memfasilitasi teman-teman kepengurusan dan mahasiswa lain untuk selalu berkomunikasi dalam setiap kegiatan. Apalagi di masa Pandemi covid 19 ini maka yang dimaksimalkan untuk berkomunikasi yakni grup whatsapp.

Selain itu saudara wahyu sebagai wakil ketua himpunan mahasiswa program studi pendidikan ekonomi menyampaikan bahwa sebelum masa pandemi covid 19 datang maka tidak hanya grup whatsapp yang digunakan melainkan terdapat kotak kritik atau saran di mading himpunan mahasiswa sehingga komunikasi dijalankan dari berbagai arah.

$$
\text { Indikator yang keempat yakni }
$$

Keterlibatan mahasiswa dalam memonitor penyelenggaraan organisasi mahasiswa. Dari hasil wawancara dengan Citra selaku ketua umum Himpunan mahasiswa program studi matematika memberikan penjelasan bahwa setiap kegiatan dimonitoring oleh dewan 
pengawas kinerja dan pembina. Tergantung kegiatan tersebut diadakan oleh divisi atau Himpunan Mahasiswa secara utuh. Jika sebuah kegiatan yang dilakukan oleh masing-masing divisi maka yang memonitoring kegiatan itu ketua umum dan pembina. Sedangkan kegiatan yang dilaksanakan dari Himpunan mahasiswa secara utuh maka yang melakukan monitoring yakni pembina HIMA dan DPK. DPK sendiri merupakan alumni dari kepengurusan HIMA tahun lalu atau mahasiswa tingkat atas yang sudah tidak menjabat lagi di HIMA.

Jadi dapat disimpulkan pada prinsip partisipasi jika dilihat dari hasil wawancara seluruh kepengurusan Himpunan Mahasiswa Universitas Pamulang itu bahwa tiga indikator berjalan baik hanya satu indikator dari partisipasi yang belum berjalan sesuai yang diharapkan yakni keterlibatan atau keaktifan anggota pengurus masih terdapat beberapa program studi yang belum sepenuhnya aktif dalam menjalankan tugasnya dengan baik di organisasi HIMA.

Menurut Cohen dan Uphoff (dalam Dwiningrum, 2011: 61-63) membedakan partisipasi menjadi empat jenis, yaitu pertama, partisipasi dalam pengambilan keputusan. Kedua, partisipasi dalam pelaksanaan. Ketiga, partisipasi dalam pengambilan pemanfaatan. Dan Keempat, partisipasi dalam evaluasi. Pertama, partisipasi dalam pengambilan keputusan. Partisipasi ini terutama berkaitan dengan penentuan alternatif dengan masyarakat berkaitan dengan gagasan atau ide yang menyangkut kepentingan bersama. Wujud partisipasi dalam pengambilan keputusan ini antara lain seperti ikut menyumbangkan gagasan atau pemikiran, kehadiran dalam rapat, diskusi dan tanggapan atau penolakan terhadap program yang ditawarkan. Kedua, partisipasi dalam pelaksanaan meliputi menggerakkan sumber daya dana, kegiatan administrasi, koordinasi dan penjabaran program. Partisipasi dalam pelaksanaan merupakan kelanjutan dalam rencana yang telah digagas sebelumnya baik yang berkaitan dengan perencanaan, pelaksanaan maupun tujuan. Ketiga, partisipasi dalam pengambilan manfaat. Partisipasi dalam pengambilan manfaat tidak lepas dari hasil pelaksanaan yang telah dicapai baik yang berkaitan dengan kualitas maupun kuantitas. Dari segi kualitas dapat dilihat dari output, sedangkan dari segi kuantitas dapat dilihat dari persentase keberhasilan program. Keempat, partisipasi dalam evaluasi. Partisipasi dalam evaluasi ini berkaitan dengan pelaksanaan program yang sudah direncanakan sebelumnya. Partisipasi dalam evaluasi ini bertujuan untuk mengetahui ketercapaian program yang sudah direncanakan sebelumnya.

Prinsip good governance kedua yang menjadi objek penelitian ini yakni prinsip akuntabilitas. Konsep akuntabilitas berawal dari pemikiran bahwa, setiap kegiatan harus dipertanggungjawabkan kepada orang atau instansi yang memberi kewenangan untuk melaksanakan suatu program, seperti yang dinyatakan oleh Basri, F. H., \& Munandar, H (2009) bahwa, akuntabilitas merupakan kewajiban dari individu-individu atau penguasa yang dipercayakan untuk mengelola sumber daya publik dan yang bersangkutan dengannya untuk dapat menjawab hal-hal yang menyangkut kebijakan fiskal, manajerial dan program. 30) akuntabilitas adalah instrument pertanggungjawaban keberhasilan dan kegagalan tugas pokok dan fungsi serta misi organisasi. Konsep akuntabilitas dalam penelitian ini yaitu pertanggungjawaban organisasi mahasiswa universitas Pamulang sebagai pelaksana kegiatan yang berkaitan dengan kemahasiswaan yang berkewajiban untuk melaporkan segala kegiatan terutama dalam bidang administrasi keuangan kepada pihak yang lebih tinggi dan 
pertanggungjawaban baik di tingkat Himpunan Mahasiswa maupun tingkat kampus.

Di dalam organisasi mahasiswa pada universitas pamulang diarahkan agar pelaksanaan organisasi memenuhi prinsip akuntabilitas agar tercapainya good governance dalam sebuah organisasi. HIMA Universitas pamulang memiliki AD ART dimana semua kegiatan mengikuti dasar hukum atau kebijakan tersebut. Pasal yang mengatur tentang prinsip akuntabilitas terdapat pada pasal 16 ayat 2 point 3 AD ART HIMA yang isinya bahwa pengurus berkewajiban mempersiapkan laporan pertanggungjawaban pada masa akhir jabatannya satu bulan sebelum dilaksanakannya Mubes.

Dari hasil wawancara tentang prinsip akuntabilitas dengan ketua umum HIMA Program Studi sekretaris saudari saskia bahwa laporan setiap kegiatan selalu dibuat diakhir kegiatan yang dikemudian diarsipkan. Mubes dilaksanakan di akhir tahun masa jabatan sedangkan dokumen-dokumen kegiatan selalu dibuat setelah selesai kegiatan dan disimpan untuk Mubes.

Pendapat lain disampaikan oleh ketua HIMA Program Studi Sastra Inggris Rian Indra Fadilla menyampaikan bahwa pertama, laporan dari setiap kegiatan HIMA selalu dibuat walau masih ada beberapa komponen masih ada kekurangan. Laporan hanya sampai kepada Pembina dan Kaprodi. Tergantung jenis kegiatannya juga. Jika kegiatan hanya ruang lingkup prodi maka laporan disampaikan hanya pada kaprodi, kegiatan dengan ruang lingkup yang lebih luas misal yang melibatkan antar program studi maka laporan sampai kepada Wakil Rektor 3 bidang kemahasiswaan dan Rektor. Kedua, jika ada kegiatan yang tidak bisa dijalankan maka akan diberikan penjelasan kepada pihak-pihak terkait mengapa kegiatan tersebut tidak berjalan atau batal. Biasanya pemberian kejelasan tersebut dilakukan dengan sosialisasi di Whatsapp grup dan datang ke setiap kelas. Kedua, pada masa pandemi covid 19 ini banyak kegiatan yang tertunda. Kepengurusan terutama bidang Humas berperan aktif menginformasikan kepada mahasiswa dan pihak lainnya bahwa kegiatan belum bisa dilaksanakan karena untuk menjaga diri dari terpaparnya virus dan mengikuti instruksi pemerintah dan pihak kampus untuk tidak melaksanakan kegiatan yang mengundang kerumunan massa. Hampir semua ketua HIMA menjelaskan hal yang sama terkait akuntabilitas. Dari hasil wawancara tersebut bahwa implementasi prinsip akuntabilitas pada organisasi mahasiswa universitas pamulang telah berjalan sesuai dengan Indikator prinsip akuntabilitas menurut Kurniawan (Lalolo, 2003: 17) akuntabilitas dalam penyelenggaraan pemerintahan terdiri dari beberapa elemen antara lain:

1. Adanya akses publik terhadap laporan yang telah dibuat

2. Penjelasan dan pembenaran terhadap tindakan pemerintah

3. Penjelasan harus dilakukan dalam sebuah forum terbuka

4. Aktor harus memiliki kewajiban untuk hadir.

Prinsip good governance ketiga yang menjadi objek penelitian ini yakni prinsip transparansi. Yang dimaksud dalam prinsip transparansi dalam penelitian ini yakni mengenai keterbukaan pertanggungjawaban kepengurusan HIMA dari setiap Program Studi di Universitas Pamulang kepada mahasiswa dan Pembina maupun Kaprodi. Sesuai dengan apa yang disampaikan Humanitarian Forum Indonesia (HFI) terdapat 6 prinsip transparansi yaitu:

1. Adanya informasi yang mudah dipahami dan diakses (dana, cara pelaksanaan, bentuk bantuan atau program).

2. Adanya publikasi dan media mengenai proses kegiatan dan detail keuangan.

3. Adanya laporan berkala mengenai 
pendayagunaan sumber daya dalam perkembangan proyek yang dapat diakses oleh umum.

4. Laporan tahunan

5. Website atau media publikasi organisasi

6. Pedoman dalam penyebaran informasi

Indikator pertama tentang transparansi yakni adanya jaminan hukum/dasar hukumnya. Dasar hukum prinsip transparansi pada organisasi mahasiswa atau HIMA universitas Pamulang diatur dalam AD ART. Dimana dijelaskan pada bagian $\mathrm{V}$ pasal 19 tentang macam-macam rapat pada point no 4 disebutkan bahwa rapat pertanggungjawaban dihadiri oleh seluruh pengurus HIMA untuk membahas pertanggungjawaban hasil kegiatan. Yang dimaksud pertanggungjawaban disini tidak hanya dari segi dokumen atau laporan kegiatan tapi masalah keuangan pun disampaikan secara detail agar tercapainya transparansi dalam segala hal.

Indikator kedua yakni aksesibilitas dokumen HIMA. Hasil wawancara dengan Yogi P ketua HIMA Program studi teknik mesin mengenai transparansi dokumen maupun laporan kegiatan bahwa kelengkapan dokumen termasuk Laporan Pertanggung jawaban disampaikan kepada pihak-pihak yang terkait seperti Pembina dan kaprodi serta dewan pengawas pada saat Musyawarah Besar. Semua mengenai kegiatan dan anggaran disampaikan. Aprizal Mulya Pramana ketua umum HIMA Teknik kimia pun menambahkan bahwa setiap laporan dibagikan atau di share melalui grup Whatsapp ketua kelas agar rekan mahasiswa mengetahui segala laporan yang dilaksanakan oleh HIMA jadi tidak hanya kegiatannya saja yang disampaikan ke mahasiswa lainnya akan tetapi laporan pun disampaikan. Dari hasil wawancara yang dilakukan ke 15 program studi masalah transparansi dokumen yang benarbenar menshare laporan kegiatan tanpa diminta oleh mahasiswa lain itu hanya ada beberapa program studi seperti prodi pendidikan pancasila dan kewarganegaraan, prodi pendidikan ekonomi, prodi Matematika, prodi teknik kimia. Untuk prodi lainnya hanya memberikan dokumen jika mahasiswa lainnya meminta dokumen tersebut.

Indikator ketiga yakni kelengkapan dokumentasi. Dari 15 program studi menjelaskan bahwa selalu berupaya untuk memenuhi kelengkapan dokumen dari setiap kegiatan. Walau terjadi kekurangan akan tetapi terus ditingkatkan kelengkapan dokumen tersebut.

Indikator yang keempat yakni keterbukaan segala proses kegiatan HIMA. Hasil wawancara yang didapatkan dari setiap program studi bahwa setiap kegiatan yang akan dilaksanakan HIMA maka akan selalu diinformasikan kepada mahasiswa di Prodi tersebut kemudian segala bentuk prosesnya juga dilaporkan dengan rinci. Deni saputra (ketua umum HIMA Program Studi pendidikan pancasila dan kewarganegaraan) menambahkan bahwa HIMA selalu update kegiatan di media sosial baik Instagram maupun grup whatsapp agar tercipta kepercayaan mahasiswa kepada kepengurusan HIMA di setiap Program Studi.

Keempat indikator prinsip transparansi sesuai Kristianten (2006:73) menyebutkan bahwa transparansi dapat diukur melalui beberapa indikator :

1. Kesediaan dan aksesibilitas dokumen

2. Kejelasan dan kelengkapan informasi

3. Keterbukaan proses

4. Kerangka regulasi yang menjamin transparansi.

Dari penjelasan di atas dapat disimpulkan bahwa implementasi good governance pada prinsip transparansi HIMA Universitas Pamulang berjalan baik mengikuti ketentuan yang berlaku hanya perlu ditingkatkan pada indikator publikasi dokumen agar bisa dilaksanakan oleh semua HIMA program studi Sehingga meningkatnya kepercayaan dan 
kepuasan publik atau mahasiswa terhadap kepengurusan organisasi mahasiswa dan timbulnya kesadaran mahasiswa tentang hak untuk menilai penyelenggaraan HIMA.

\section{Kesimpulan}

Implementasi pada prinsip partisipasi belum sepenuhnya berjalan baik pada kepengurusan Himpunan Mahasiswa Universitas Pamulang itu karena rata-rata baru menjalankan 3 (tiga) indikator yakni ketersediaan dasar hukum kegiatan, memiliki media atau forum sebagai wadah komunikasi kegiatan, dan memonitoring setiap kegiatan. Sedangkan partisipasi keaktifan kepengurusan hanya 8 program studi yang seluruh anggotanya aktif. Prodi lainnya tidak sepenuhnya aktif karena beberapa faktor yakni pertama masalah waktu, banyaknya anggota kepengurusan yang mempunyai kesibukan diluar dari kegiatan perkuliahan. Kedua masalah jarak dari rumah ke kampus yang cukup jauh sehingga terkendala. Ketiga, masalah ekonomi yang membuat kurang sertanya partisipasi anggota kepengurusan

Selanjutnya implementasi prinsip akuntabilitas pada organisasi mahasiswa universitas Pamulang sudah sepenuhnya dijalankan sesuai Pasal yang mengatur tentang prinsip akuntabilitas terdapat pada pasal 16 ayat 2 point 3 AD ART HIMA yang isinya bahwa pengurus berkewajiban mempersiapkan laporan pertanggungjawaban pada masa akhir jabatannya satu bulan sebelum dilaksanakannya MUBES. Dari hasil wawancara dengan seluruh organisasi Universitas Pamulang bahwa setiap kegiatan selalu ada Laporan yang dibuat untuk dipertanggungjawabkan.

Selain itu pelaksanaan prinsip transparansi pada organisasi mahasiswa atau HIMA universitas Pamulang dari hasil wawancara implementasi good governance pada prinsip transparansi HIMA Universitas Pamulang berjalan cukup baik mengikuti ketentuan yang berlaku hanya perlu ditingkatkan pada indikator publikasi dokumen agar bisa dilaksanakan oleh semua HIMA program studi Sehingga meningkatnya kepercayaan dan kepuasan publik atau mahasiswa terhadap kepengurusan organisasi mahasiswa dan timbulnya kesadaran mahasiswa tentang hak untuk menilai penyelenggaraan HIMA. Karena yang melaksanakan publikasi dokumen kegiatan tanpa diminta terlebih dahulu oleh mahasiswa lain yakni ada 4 HIMA

Seperti HIMA prodi pendidikan pancasila dan kewarganegaraan, HIMA prodi pendidikan ekonomi, HIMA prodi Matematika, HIMA prodi teknik kimia. Untuk prodi lainnya hanya memberikan dokumen jika mahasiswa lainnya meminta dokumen tersebut.

Oleh karena itu, diperlukan peningkatan dalam pelaksanaan prinsip partisipasi dan transparansi pada seluruh HIMA universitas Pamulang agar terciptanya good student governance dan memberikan dampak nyata dalam meningkatkan visi misi Universitas.

\section{Referensi}

Adisasmita, R. 2011. Manajemen Pemerintahan Daerah. Makassar: Graha Ilmu.

Basri, F. H., \& Munandar, H. (2009). Lanskap ekonomi Indonesia: kajian dan renungan terhadap masalah-masalah struktural, transformasi baru, dan prospek perekonomian Indonesia. Jakarta: Kencana.

Dwiningrum, S. I. A. (2011). Desentralisasi dan partisipasi masyarakat dalam pendidikan. Yogyakarta: Pustaka Pelajar. 
Jurnal Pendidikan Kewarganegaraan

Vol. 7 No. 2 September 2020

Kristianten. 2006. Transparansi Anggaran Pemerintah. Jakarta :Rineka Cipta.

Lalolo. K. P. L. 2003. Indikator dan Alat Ukur Prinsip Akuntabiitas, Transparansi dan Partisipasi. Jakarta: Bappenas.
Journal of Civics and Education Studies p-ISSN 2302-0865 | e-ISSN 2621-346X

Siregar, M. R., Prasetya, S., Prananto, H., Yuniawati, E., \& Sarsa, N. U. (2016). Implementasi Good Governance pada Organisasi Mahasiswa di Universitas Gadjah Mada Demi Mewujudkan Good Student Governance. Jurnal Penelitian Hukum-Fakultas Hukum Universitas Gadjah Mada, 3(1), 56-69. 